\title{
Influence of Noble Metal Coating on Wettability of Copper Substrate by Sn-Ag Eutectic Solder
}

\author{
Hisaaki Takao ${ }^{1}$ and Hideo Hasegawa ${ }^{1}$ \\ ${ }^{1}$ TOYOTA CENTRAL R\&D LABS., INC., Nagakute, Aichi 480-1192, Japan
}

\begin{abstract}
The influence of thin coatings ( $70 \mathrm{~nm}$ ) of $\mathrm{Au}, \mathrm{Ag}$ and $\mathrm{Pd}$ on the wettability of a Cu substrate by a $\mathrm{Sn}-3.5 \mathrm{Ag}$ eutectic solder was investigated using the contact angle measuring system combined with meniscograph tester. The wettability of the $\mathrm{Cu}$ substrate with $\mathrm{Sn}-3.5 \mathrm{Ag}$ was improved by the Au and Ag coatings, while reduced by a Pd coating, especially in terms of the contact angle. Namely, the contact angles were $29-30^{\circ}$ on the $\mathrm{Au}$ coated- $\mathrm{Cu}$ substrate, $34-35^{\circ}$ on the $\mathrm{Ag}$ coated- $\mathrm{Cu}$ substrate, $49-52^{\circ}$ on the Pd coated-Cu substrate and $42-45^{\circ}$ on the uncoated $\mathrm{Cu}$ substrate. On the wetted area, each coating layer dissolved into the solder and the $\mathrm{Cu}-\mathrm{Sn}$ intermetallic compound was formed at the solder/ substrate interface as well as on the uncoated $\mathrm{Cu}$ substrate, but the coating metal layers remained on the unwetted area. The difference in wettability of the noble metal coating on the $\mathrm{Cu}$ substrate was found to be attributed to the difference in the substrate-flux interfacial tensions $\left(\gamma_{\mathrm{sf}}\right)$.
\end{abstract}

(Received September 22, 2003; Accepted January 26, 2004)

Keywords: lead free solder, noble metal, coating, wettability, contact angle, interfacial tension, meniscograph method

\section{Introduction}

From the viewpoint of global environmental preservation, the development of solders without containing $\mathrm{Pb}$ as a hazardous substance, the so-called $\mathrm{Pb}$-free solders, has been conducted on a worldwide basis. ${ }^{1)}$ Much insecurity about the mechanical and electrical reliability of $\mathrm{Pb}$-free soldered connections remains, because the wettability of $\mathrm{Pb}$-free solder is quite inferior to that of a $\mathrm{Sn}-\mathrm{Pb}$ eutectic solder. ${ }^{2-5)}$ While $\mathrm{Pb}$-free coating materials, for example, $\mathrm{Au} / \mathrm{Ni}, \mathrm{Pd} / \mathrm{Ni}$, $\mathrm{Sn}, \mathrm{Sn}-\mathrm{Ag}$ and $\mathrm{Sn}-\mathrm{Bi}$, on the electrode surface of a printed wiring board (PWB) and electronic device have been investigated, ${ }^{6-9)}$ the wettability of the $\mathrm{Pb}$-free coating material on the electrode surface by $\mathrm{Pb}$-free solder has not been sufficiently clarified.

The meniscograph method is one of the most useful methods to evaluate solder wettability. The wetting force can be measured as a product of the contact angle $(\theta)$ and the molten solder-flux interfacial tension $\left(\gamma_{\text {lf }}\right)$, which are physical parameters of wettability. However, it is difficult to measure both $\theta$ and $\gamma_{\text {If }}$ separately by a conventional equipment. In the conventional method, the maximum wetting force, wetting time (between the time immersion starts and that when the force on a substrate returns to zero) and wetting rate, all of which are obtained from the wetting force-time curve, are used only as wettability indices. ${ }^{10)}$ Unfortunately, these indices are easily affected by the substrate size and shape, so that wettability cannot be quantitatively evaluated but only qualitatively.

We have developed a new system combined with an instrument to directly measure $\theta$ during the solder wetting process. ${ }^{11,12)}$ In this system, the contact angle $(\theta)$, interfacial tension $(\gamma)$ and the wettability indices in the meniscograph method can be measured simultaneously. The principle for measuring the contact angle utilizes the regular reflection characteristic of the molten solder surface which possesses a specular gloss. Consequently, the direction angle of the solder fillet surface can be measured without contact.

In this study, using this newly developed system, ${ }^{11,12)}$ the influence of the coating noble metals, $\mathrm{Au}, \mathrm{Ag}$, and $\mathrm{Pd}$, on the wettability of a $\mathrm{Cu}$ substrate with the $\mathrm{Sn}-\mathrm{Ag}$ eutectic solder was investigated on the basis of physical parameters, i.e., the contact angle $(\theta)$ and interfacial tensions $(\gamma)$ between the solder, flux and substrate.

\section{Experimental}

\subsection{Contact angle measurement}

A schematic illustration of the meniscograph method is shown in Fig. 1. The force-time curve during wetting of a substrate by the solder, the so-called wetting curve, is shown in Fig. 1(a). The $t_{0}, t_{1}, t_{2}$ and $t_{3}$ are times when the substrate contacts the solder surface $(t=0 \mathrm{~s})$, the solder begins to wet the substrate, the force on the substrate returns to zero and the wetting becomes stable (the wetting force almost reaches a constant value), respectively.

Figure 1(b) shows the relationship among the wetting force $(F)$, the solder-flux interfacial tension $\left(\gamma_{\text {lf }}\right)$ and contact angle $(\theta)$. When $F$ and $\theta$ are measured, $\gamma_{\text {lf }}$ can be immediately obtained from eq. (1). ${ }^{13)}$

$$
F=P \times \gamma_{\mathrm{lf}} \times \cos \theta-B
$$

where $P$ is the perimeter of the substrate and $B$ is the buoyancy force, both of which are known to be constants. Thus, the solder wettability can be analyzed from the viewpoint of interfacial tension.

Figure 2 shows the construction of the contact angle and interfacial tension measuring system combined with the meniscograph method. The principle of the contact angle measurement utilizes the regular reflection characteristic of the molten solder surface which possesses a specular gloss. The multiple light sources with a distinctive brightness simultaneously irradiate the molten solder surface, and the reflection is recorded with a CCD camera. Subsequently, the reflection on each pixel received by the CCD camera is related to the position of the light source by using the regular reflection characteristic at the molten solder fillet surface. Consequently, the direction angle of the solder fillet surface 
(a)

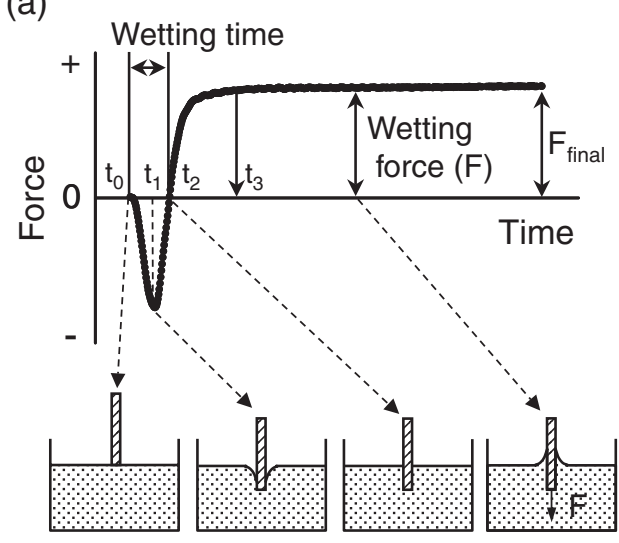

(b)

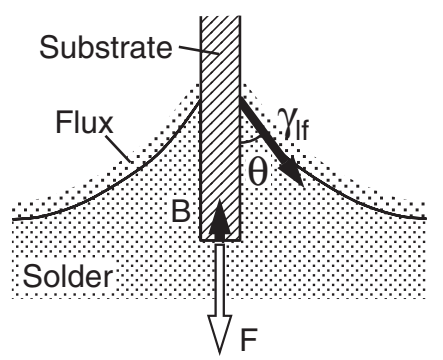

Fig. 1 Schematic illustration of meniscograph method; (a) wetting curve and (b) vertical schematic illustration of the substrate immersed in the molten solder.

\section{Meniscograph tester $\begin{gathered}\text { Contact angle } \\ \text { measuring instrument }\end{gathered}$}

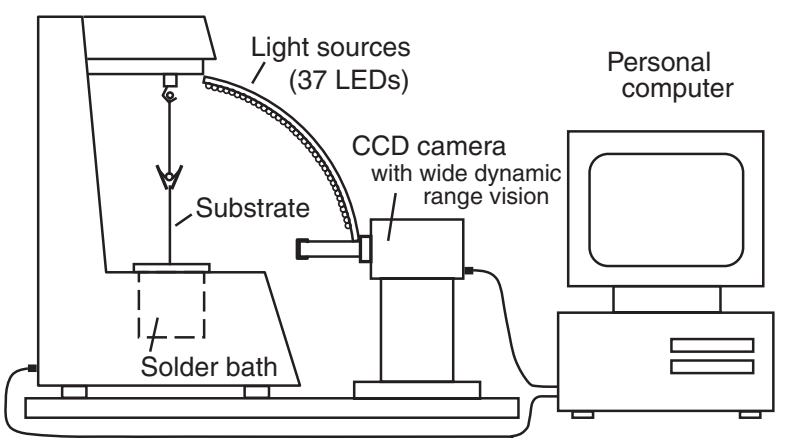

Fig. 2 Construction of the contact angle and surface tension measuring system for soldering.

can be measured without contact.

The following three techniques are developed in order to achieve a high speed (15 frame/s) and highly accurate $\left( \pm 0.2^{\circ}\right)$ measurement.

1) The first technique is that, in order to improve the angular resolution of this equipment, multiple light sources (37 LEDs) are accurately arranged at an interval of $2.2^{\circ}$ so as to uniformly irradiate the solder fillet surface as shown in Fig. 2. The contact angle can be measured in the range of 4 $71^{\circ}$ by changing the position of the CCD camera. The LED devices emitting near-infrared light (wavelength: $880 \mathrm{~nm}$ ) were selected in order to suppress the influence of visible light.

2) The second technique uses brightness-ratio-coded light (a)

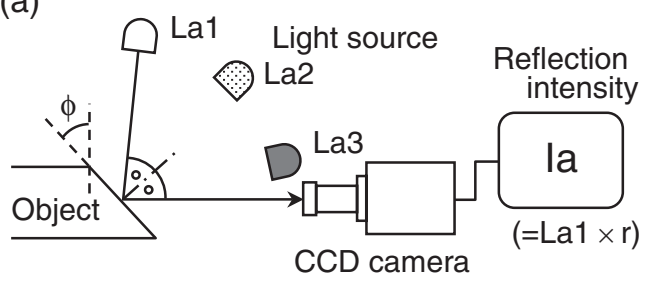

(b)

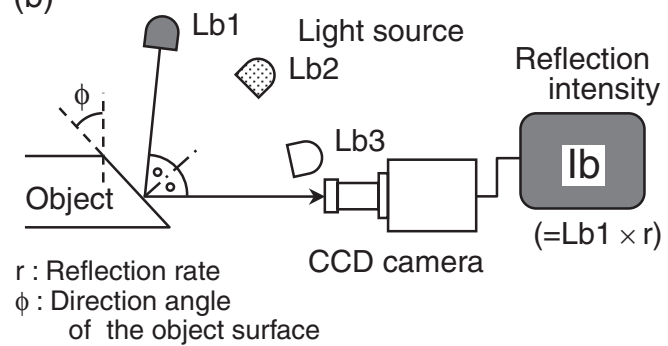

Fig. 3 Schematic illustration of the brightness-ratio-coded method; (a) lighting pattern A (brightness: La1>La2>La3) and (b) lighting pattern B (brightness: Lb1 $<\mathrm{Lb} 2<\mathrm{Lb} 3$ ).

sources, as shown in Fig. 3. This allows us to specify the position of the light source from the ratio of the reflection intensity obtained under two different flashing patterns. As can be seen in eq. (2), by reduction of the reflection rate, the ratio of the reflection intensity has to equal that of the light source brightness which is a known constant.

$$
\mathrm{Ia} / \mathrm{Ib}=(\mathrm{La} 1 \times r) /(\mathrm{Lb} 1 \times r)=\mathrm{La} 1 / \mathrm{Lb} 1
$$

where Ia and Ib are the reflection intensities, La1 and Lb1 are the brightness of the light sources, and $r$ is the reflection rate of the solder surface. Therefore, by measuring the ratio of the reflection intensity, the position of the light source, hence, the direction angle $(\phi)$ of the solder fillet surface can be measured.

3) The third technique is the enlargement of the dynamic range of the CCD camera by synthesizing two pictures obtained under two different exposure times, which allows one to record the subject with a wide range of contrast such as the molten solder surface. ${ }^{14)}$

By continuously taking four pictures at fixed intervals (1/ $15 \mathrm{~s}$ ) during the solder wetting test, the distribution data of the direction angle of the solder fillet surface were obtained, followed by measuring the contact angle and interfacial tension. The performance of the contact angle measuring instrument is shown in Table 1.

\subsection{Wettability evaluation and analysis}

Table 2 shows the soldering test conditions. The composition of the solder was 96.5 mass $\% \mathrm{Sn}-3.5 \mathrm{mass} \% \mathrm{Ag}$ (described as $\mathrm{Sn}-\mathrm{Ag}$ hereafter). As the substrate, $\mathrm{Cu}$, Au-coated $\mathrm{Cu}$ (described as $\mathrm{Au} / \mathrm{Cu}$ hereafter), $\mathrm{Ag}$-coated $\mathrm{Cu}$ (described as $\mathrm{Ag} / \mathrm{Cu}$ hereafter), and $\mathrm{Pd}$-coated $\mathrm{Cu}$ (described as $\mathrm{Pd} / \mathrm{Cu}$ hereafter) plates were used. The size of substrate was $10 \times 30 \times 0.3 \mathrm{~mm}^{3}$, and each noble metal coating of $70 \mathrm{~nm}$ in thickness was deposited on the $\mathrm{Cu}$ plate by sputtering. Before the wettability test and coating with the noble metal, the $\mathrm{Cu}$ plate surface was cleaned by electrolytic polishing, followed by etching with $1 \mathrm{M} \mathrm{HCl}$, washed in ion-exchange 
Table 1 Performance of contact angle measuring instrument.

\begin{tabular}{lc}
\hline Sampling area $\left(\mathrm{mm}^{2}\right)$ & $3.16(\mathrm{X}) \times 2.45(\mathrm{Y})$ \\
\hline Resolution (pixel) & $640(\mathrm{H}) \times 240(\mathrm{~V})$ \\
\hline Measured angle range*1 & (1) $4-42^{\circ},(2) 18-56^{\circ},\left(333-71^{\circ}\right.$ \\
\hline Accuracy of angle ${ }^{* 2}$ & $\pm 0.2^{\circ}$ \\
\hline Sampling rate (frames max./sec) & 15 \\
\hline *1: It can be selected by the setting angle of CCD camera on a horizontal level. \\
$* 2:$ Maximum fluctuation of one pixel is $\pm 2^{\circ}$.
\end{tabular}

Table 2 Soldering test conditions.

\begin{tabular}{lc}
\hline Solder & 96.5 mass $\%$ Sn-3.5 mass $\% \mathrm{Ag}$ \\
\hline Temperature & $250,270,290^{\circ} \mathrm{C}$ \\
\hline Substrate & $\mathrm{Cu}, \mathrm{Au}, \mathrm{Ag}, \mathrm{Pd}$ \\
\hline Coating metal on Cu substrate & $\mathrm{Au}, \mathrm{Ag}, \mathrm{Pd}$ (thickness: $70 \mathrm{~nm}$ ) \\
\hline Flux & PO-Z-7 (halogen-free) \\
\hline Atmosphere & Air \\
\hline Immersion time & $10 \mathrm{~s}$ \\
\hline Immersion depth & $2 \mathrm{~mm}$ \\
\hline Immersion rate & $\pm 10 \mathrm{~mm} / \mathrm{s}$ \\
\hline Repetition & 3 \\
\hline
\end{tabular}

water and then air dried. In addition, the wettabilities of pure $\mathrm{Au}(99.99 \%), \mathrm{Ag}(99.99 \%)$ and $\mathrm{Pd}(99.95 \%)$ substrates, having a size of $10 \times 30 \times 0.3 \mathrm{~mm}^{3}$, were also investigated for the comparison with those of the $\mathrm{Au} / \mathrm{Cu}, \mathrm{Ag} / \mathrm{Cu}$ and $\mathrm{Pd} /$ $\mathrm{Cu}$ substrates. The soldering temperature was measured at a depth of $3 \mathrm{~mm}$ from the surface of the molten solder alloy with a thermocouple.

The contact angle $(\theta)$ and wetting force $(F)$ were measured $5 \mathrm{~s}$ after the immersion began. In this study, the wetting time $\left(t_{2}\right.$ in Fig. 1(a)), maximum wetting force $\left(F_{\max }\right)$ and contact angle $(\theta)$ were used to evaluate the wettability.

Figure 4 is a schematic illustration of the wetting. The contact angle is determined as a result of the balance of three interfacial tensions at the wetting tip of the solder, i.e., the solder-flux $\left(\gamma_{\text {lf }}\right)$, substrate-flux $\left(\gamma_{\mathrm{sf}}\right)$ and substrate-solder interfacial tension $\left(\gamma_{\mathrm{sl}}\right)$. This relationship ${ }^{15)}$ is described by Young's eq. (3).

$$
\gamma_{\mathrm{sf}}=\gamma_{\mathrm{lf}} \times \cos \theta+\gamma_{\mathrm{sl}}
$$

The solder-flux interfacial tension $\left(\gamma_{\text {lf }}\right)$ can be obtained by substituting $F$ and $\theta$ in eq. (1). In addition, by using eqs. (1) and (3), the difference in $\gamma_{\mathrm{sf}}$ and $\gamma_{\mathrm{sl}}$ can be obtained. Consequently, the wettability between the molten solder and substrate can be analyzed from the viewpoint of the

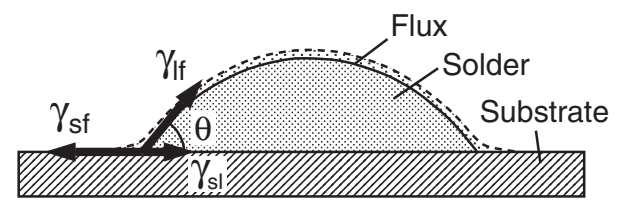

Fig. 4 Sessile drop geometry determined by the equilibrium relationship between interfacial tensions which are the solder/flux, substrate/flux and substrate/solder. interfacial tensions which are physical parameters.

Furthermore, the intermetallic compound, which is formed at the interface between the solder and each substrate, was investigated by X-ray diffraction. The sample was prepared by removing the solder on the substrate using an aqueous solution of 15 volume \% nitric acid.

\section{Results and Discussion}

Figure 5 shows the wetting curves of the $\mathrm{Au} / \mathrm{Cu}, \mathrm{Ag} / \mathrm{Cu}$, $\mathrm{Pd} / \mathrm{Cu}$ and $\mathrm{Cu}$ substrates wetted by the $\mathrm{Sn}-\mathrm{Ag}$ solder between 250 and $290^{\circ} \mathrm{C}$. In Fig. 6, the wetting time ( $t_{2}$ in Fig. 1(a)) and the time to reach the stable wetting ( $t_{3}$ in Fig. 1(a)) for each substrate wetted by the Sn-Ag solder are shown as a function of the soldering temperature. For all the substrates, both $t_{2}$ and $t_{3}$ decrease with an increase in temperature.

In addition, $t_{2}$ and $t_{3}$ for the $\mathrm{Cu}$ substrate wetted by the $\mathrm{Sn}$ $\mathrm{Pb}$ eutectic solder at $230^{\circ} \mathrm{C}$ (eutectic temp. $+50^{\circ} \mathrm{C}$ ) is shown as a cross on the vertical axis for reference.

In Fig. 6(a), for the $\mathrm{Au} / \mathrm{Cu}$ and $\mathrm{Ag} / \mathrm{Cu}$ substrates, the $t_{2}$ values are comparable to that for the $\mathrm{Cu}$ substrate, while $t_{2}$ value for the $\mathrm{Pd} / \mathrm{Cu}$ substrate is slightly longer than that for the other substrates. Additionally, many of the $t_{2}$ values for the $\mathrm{Sn}-\mathrm{Ag}$ solder are longer than that for the $\mathrm{Sn}-\mathrm{Pb}$ solder wetting $\mathrm{Cu}$ substrate (the cross in Fig. 6(a)).

In the case of the $\mathrm{Sn}-\mathrm{Ag}$ solder, in order to obtain the wetting time $\left(t_{2}\right)$ which is comparable to the case of the Sn$37 \mathrm{~Pb}$ solder wetting $\mathrm{Cu}$ substrate at $230^{\circ} \mathrm{C}$ (i.e., $0.76 \mathrm{~s}$ ), the soldering temperature had to be shifted to a higher temperature, namely, $270^{\circ} \mathrm{C}$ for the $\mathrm{Au} / \mathrm{Cu}$ and $\mathrm{Ag} / \mathrm{Cu}$ substrates, and beyond $270^{\circ} \mathrm{C}$ for the $\mathrm{Pd} / \mathrm{Cu}$ substrate.

On the other hand, as shown in Fig. 6(b), $t_{3}$ values for the $\mathrm{Ag} / \mathrm{Cu}, \mathrm{Pd} / \mathrm{Cu}$ and $\mathrm{Cu}$ substrates show similar values, but $t_{3}$ value for the $\mathrm{Au} / \mathrm{Cu}$ substrate is much longer than those of the other substrates. This is considered to be attributed to the difference in the dissolution rates between the coating metals and $\mathrm{Cu}$ into the molten $\mathrm{Sn}-\mathrm{Ag}$ solder, or difference in the effect of the flux on the wettability among the substrates.

Figure 7 shows the maximum wetting force $\left(F_{\max }\right)$. The maximum wetting force for the $\mathrm{Cu}$ substrate wetted by the $\mathrm{Sn}-\mathrm{Pb}$ eutectic solder at $230^{\circ} \mathrm{C}$ is shown as a cross on the vertical axis for reference.

At each temperature, for the $\mathrm{Au} / \mathrm{Cu}$ and $\mathrm{Ag} / \mathrm{Cu}$ substrates, $F_{\text {max }}$ is larger than that for the $\mathrm{Cu}$ substrate, while $F_{\max }$ for the $\mathrm{Pd} / \mathrm{Cu}$ substrate is smaller than that of the $\mathrm{Cu}$ substrate. Also, for each substrate, there is a slight temperature dependence of $F_{\max }$. These differences in $F_{\max }$ among the substrates is due to the difference in the magnitude of $\theta$ and $\gamma_{\mathrm{lf}}$, as will be described later.

It also was found that between 250 and $290^{\circ} \mathrm{C}, F_{\max }$ values for the $\mathrm{Au} / \mathrm{Cu}$ and $\mathrm{Ag} / \mathrm{Cu}$ substrates are larger and $F_{\max }$ value for the $\mathrm{Pd} / \mathrm{Cu}$ substrate wetted by the $\mathrm{Sn}-\mathrm{Ag}$ solder is smaller than that for the $\mathrm{Cu}$ substrate wetted by the $\mathrm{Sn}-\mathrm{Pb}$ solder (the cross in Fig. 7).

The contact angle $(\theta)$ for the wetting between the $\mathrm{Sn}-\mathrm{Ag}$ solder and each substrate is shown in Fig. 8. The contact angle for the $\mathrm{Cu}$ substrate wetted by the $\mathrm{Sn}-\mathrm{Pb}$ eutectic solder at $230^{\circ} \mathrm{C}$ is shown as a cross on the vertical axis for reference.

As shown in Fig. 8, $\theta$ ranges from 29 to $38^{\circ}$, from 34 to $35^{\circ}$, from 49 to $52^{\circ}$, and from 42 to $45^{\circ}$ for the $\mathrm{Au} / \mathrm{Cu}, \mathrm{Ag} /$ 

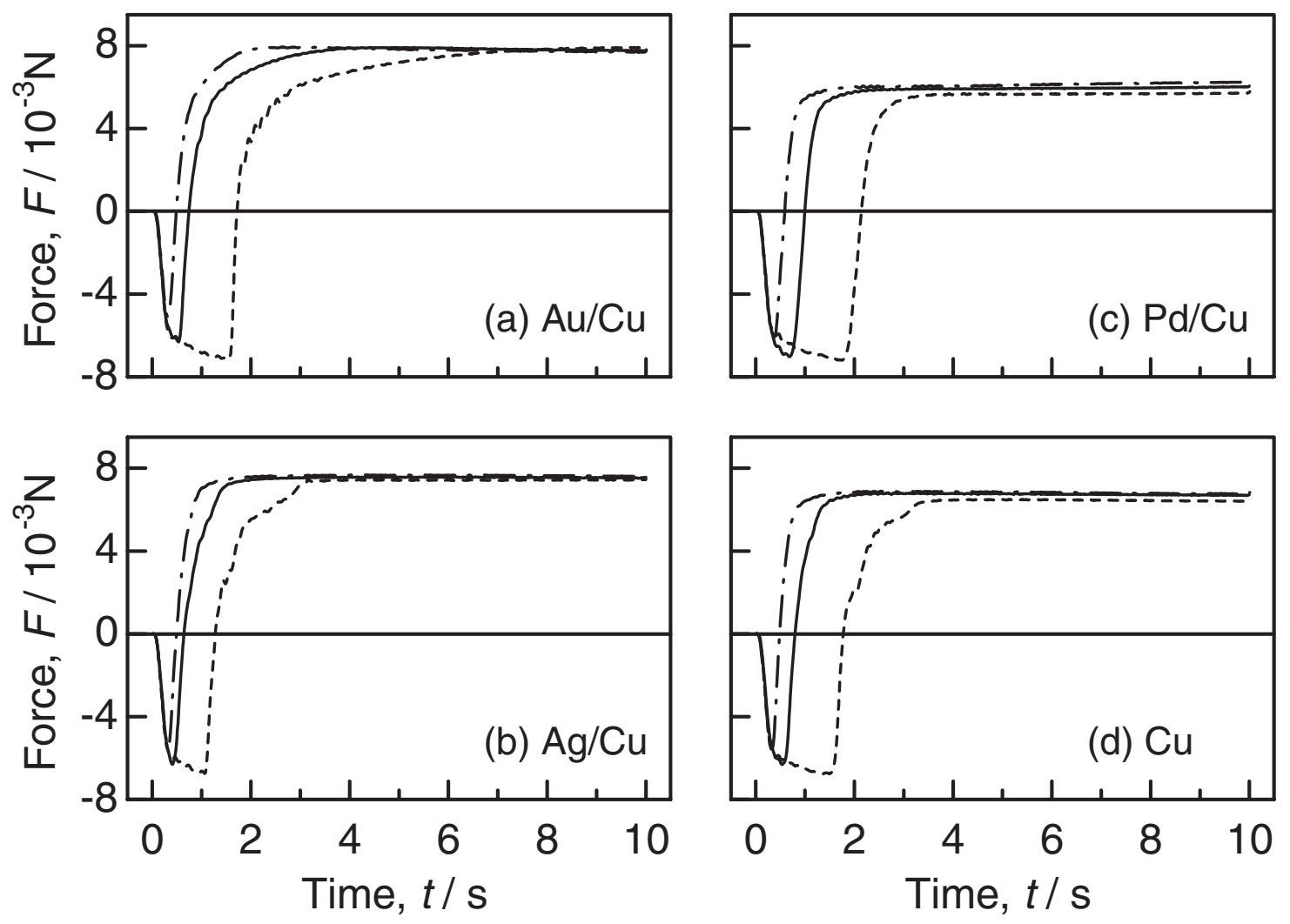

Fig. 5 Wetting curves of Sn-3.5Ag solder on the metal-coated $\mathrm{Cu}$ substrate; (a) $\mathrm{Au} / \mathrm{Cu}$, (b) $\mathrm{Ag} / \mathrm{Cu},(\mathrm{c}) \mathrm{Pd} / \mathrm{Cu}$ and (d) $\mathrm{Cu},----: 250^{\circ} \mathrm{C}$, -: $270^{\circ} \mathrm{C},-\cdot-\cdot: 290^{\circ} \mathrm{C}$.

$\mathrm{Cu}, \mathrm{Pd} / \mathrm{Cu}$ and $\mathrm{Cu}$ substrates, respectively. In other words, the wettabilities of the $\mathrm{Au} / \mathrm{Cu}$ and $\mathrm{Ag} / \mathrm{Cu}$ substrates are superior to that of the $\mathrm{Cu}$ substrate, while that of the $\mathrm{Pd} / \mathrm{Cu}$ substrate is inferior to that of the $\mathrm{Cu}$ substrate.

The value of $\theta\left(36-38^{\circ}\right)$ for the $\mathrm{Au} / \mathrm{Cu}$ substrate at $250^{\circ} \mathrm{C}$ is larger than those at the other temperatures $\left(\theta=29-30^{\circ}\right)$. This is rationalized as follows: As can be seen in Fig. 5, the wetting has not yet finished $5 \mathrm{~s}$ after the immersion began, when $\theta$ was measured. In fact, $\theta$ for the $\mathrm{Au} / \mathrm{Cu}$ substrate $9 \mathrm{~s}$ after the immersion began was $29^{\circ}$ at $250^{\circ} \mathrm{C}$. If this value is taken as the equilibrium contact angle (shown in Fig. 8 by $\left.\bigcirc^{*}\right), \theta$ at $250^{\circ} \mathrm{C}$ is comparable to that at the other temperatures. On the other hand, for the $\mathrm{Ag} / \mathrm{Cu}, \mathrm{Pd} / \mathrm{Cu}$ and $\mathrm{Cu}$ substrates, such a temperature dependence of $\theta$ between 250 and $290^{\circ} \mathrm{C}$ is not shown.

Comparison of the wetting between the $\mathrm{Sn}-\mathrm{Ag}$ solder and the $\mathrm{Sn}-\mathrm{Pb}$ solder revealed that $\theta$ for the $\mathrm{Au} / \mathrm{Cu}$ substrate wetted by the $\mathrm{Sn}-\mathrm{Ag}$ solder is comparable to that for the $\mathrm{Cu}$ substrate wetted by the $\mathrm{Sn}-\mathrm{Pb}$ solder (the cross in Fig. 8), while those for the $\mathrm{Ag} / \mathrm{Cu}$ and $\mathrm{Pd} / \mathrm{Cu}$ substrates are larger than that for the $\mathrm{Cu}$ substrate wetted by the $\mathrm{Sn}-\mathrm{Pb}$ solder.

Table 3 summarizes the relative evaluation of the wettability (wetting time, wetting force $\left(F_{\max }\right)$ and contact angle $(\theta)$ ) for the noble metal coating as compared with that for the $\mathrm{Cu}$ substrate.

The influence of the Au and Ag coatings on the wettability of the $\mathrm{Cu}$ substrate wetted by the $\mathrm{Sn}-\mathrm{Ag}$ solder is small for the wetting time, but large for $F_{\max }$ and $\theta$. Especially, the $\mathrm{Au}$ coating decreases $\theta$ from $42-45^{\circ}$ to $29-30^{\circ}$, that is, improves the wettability of the $\mathrm{Cu}$ substrate wetted by the $\mathrm{Sn}-\mathrm{Ag}$ solder. This effect by the Au coating is remarkable because $\theta$ for the $\mathrm{Au} / \mathrm{Cu}$ substrate wetted by the $\mathrm{Sn}-\mathrm{Ag}$ solder is comparable to the $\mathrm{Cu}$ substrate wetted by the $\mathrm{Sn}-\mathrm{Pb}$ solder. On the other hand, the influence of the Pd coating on the wettability of the $\mathrm{Cu}$ substrate wetted by the $\mathrm{Sn}-\mathrm{Ag}$ solder is large for the wetting time, $F_{\max }$ and $\theta$. However, its influence is negative, and causes the wettability of the $\mathrm{Pd} / \mathrm{Cu}$ substrate to be inferior to that of the $\mathrm{Cu}$ substrate.

Figure 9 shows the interfacial tension $\left(\gamma_{\mathrm{lf}}\right)$ between the $\mathrm{Sn}$ $\mathrm{Ag}$ solder and the flux evaluated using eq. (1). The $\mathrm{Sn}-\mathrm{Pb}$ solder-flux interfacial tension $\left(\gamma_{\text {lf }}\right)$ on the $\mathrm{Cu}$ substrate at $230^{\circ} \mathrm{C}$ is shown as a cross on the vertical axis for reference. In Fig. 9, the $\gamma_{\text {lf }}$ value for the $\mathrm{Au} / \mathrm{Cu}$ substrate at $250^{\circ} \mathrm{C}$ was not plotted because, as shown in Fig. 5, the wetting has not yet finished at the time when $\gamma_{\text {lf }}$ was measured $5 \mathrm{~s}$ after the immersion began.

There is no remarkable difference in $\gamma_{\text {If }}$, which shows $0.460-0.480 \mathrm{~N} / \mathrm{m}$ for all substrates. It is considered that $\gamma_{\mathrm{lf}}$ is determined by the interaction between the solder and flux, and unlikely to be influenced by the substrate. In other words, there is little change in the composition of the molten solder by the dissolution of the noble metal coating layer into the molten solder. It was also found that there is no remarkable temperature dependence of $\gamma_{\text {lf }}$ for any substrates.

From these results in Fig. 8, Fig. 9 and eq. (1), the difference in the wetting force among the substrates in Fig. 7 was found to be attributed to $\theta$, not $\gamma_{\text {lf }}$.

Figure 10 shows values of $\gamma_{\mathrm{sf}}-\gamma_{\mathrm{sl}}$ for the wetting between the $\mathrm{Sn}-\mathrm{Ag}$ solder and different substrates, evaluated using eqs. (2) and (3). Again, the cross shows $\gamma_{\mathrm{sf}}-\gamma_{\mathrm{sl}}$ for the wetting between the $\mathrm{Sn}-\mathrm{Pb}$ solder and the $\mathrm{Cu}$ substrate at $230^{\circ} \mathrm{C}$.

The $\gamma_{\mathrm{sf}}-\gamma_{\mathrm{sl}}$ values for the $\mathrm{Au} / \mathrm{Cu}$ and $\mathrm{Ag} / \mathrm{Cu}$ substrates are 

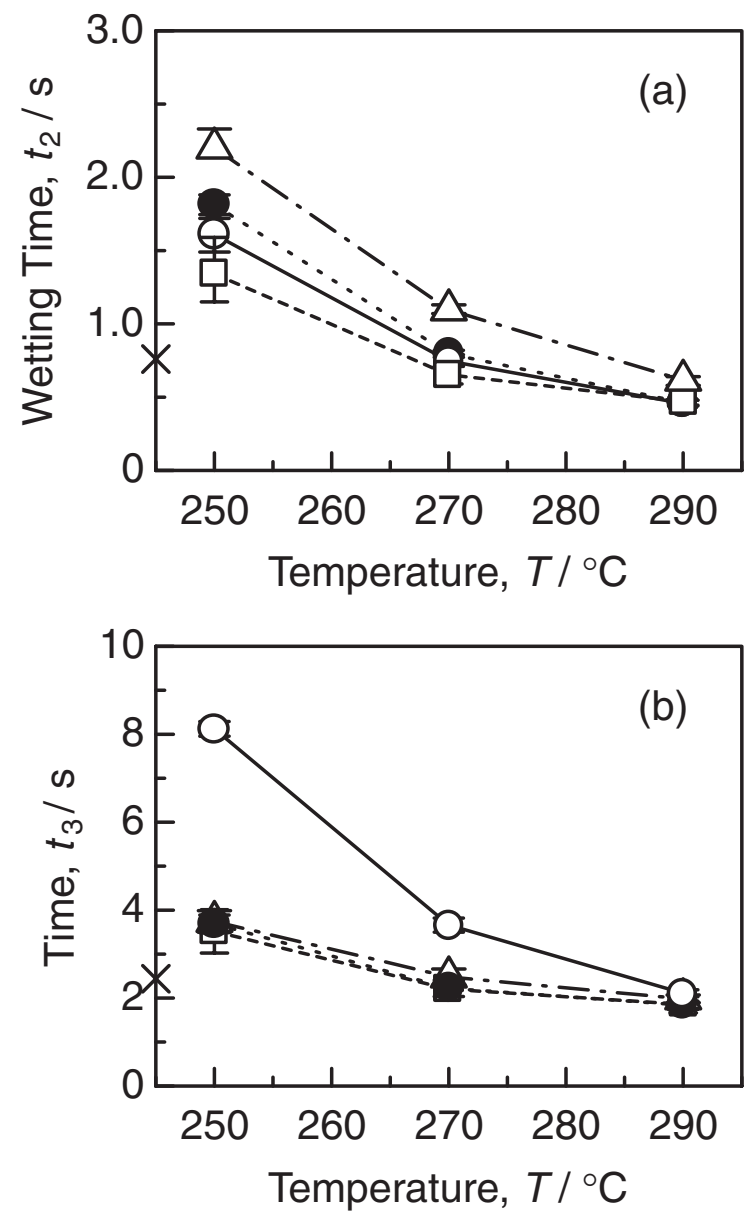

Fig. 6 Wetting time and the time to reach the stable wetting of $\mathrm{Sn}-3.5 \mathrm{Ag}$ solder on the metal-coated $\mathrm{Cu}$ substrate; (a) wetting time $\left(t_{2}\right)$, (b) the time to reach the stable wetting $\left(t_{3}\right), \bigcirc: \mathrm{Au} / \mathrm{Cu}, \square: \mathrm{Ag} / \mathrm{Cu}, \triangle: \mathrm{Pd} / \mathrm{Cu}, \bigcirc: \mathrm{Cu}$ and $\times$ : $\mathrm{Sn}-37 \mathrm{~Pb}$ wetting $\mathrm{Cu}$ substrate at $230^{\circ} \mathrm{C}$.

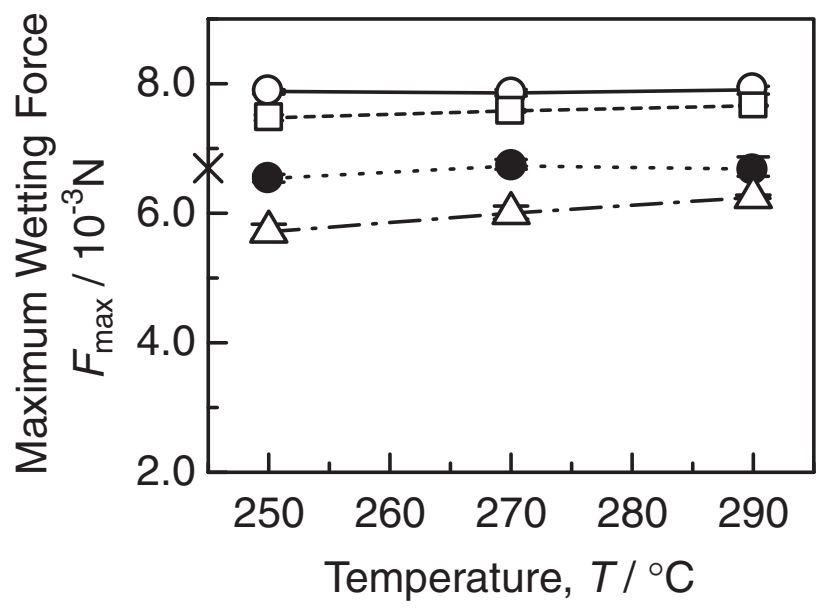

Fig. 7 Wetting force of $\mathrm{Sn}-3.5 \mathrm{Ag}$ solder on the metal-coated $\mathrm{Cu}$ substrate; $\bigcirc: \mathrm{Au} / \mathrm{Cu}, \square: \mathrm{Ag} / \mathrm{Cu}, \triangle: \mathrm{Pd} / \mathrm{Cu}, \mathrm{O}: \mathrm{Cu}$ and $\times: \mathrm{Sn}-37 \mathrm{~Pb}$ wetting $\mathrm{Cu}$ substrate at $230^{\circ} \mathrm{C}$.

larger than that for the $\mathrm{Cu}$ substrate, while that for the $\mathrm{Pd} / \mathrm{Cu}$ substrate is smaller than that for the $\mathrm{Cu}$ substrate. For all substrates, no remarkable temperature dependence of $\gamma_{\mathrm{sf}}-\gamma_{\mathrm{sl}}$ was found.

From the results mentioned above, it is concluded that the variation in $\theta$ and hence, the wettability by coating the $\mathrm{Cu}$

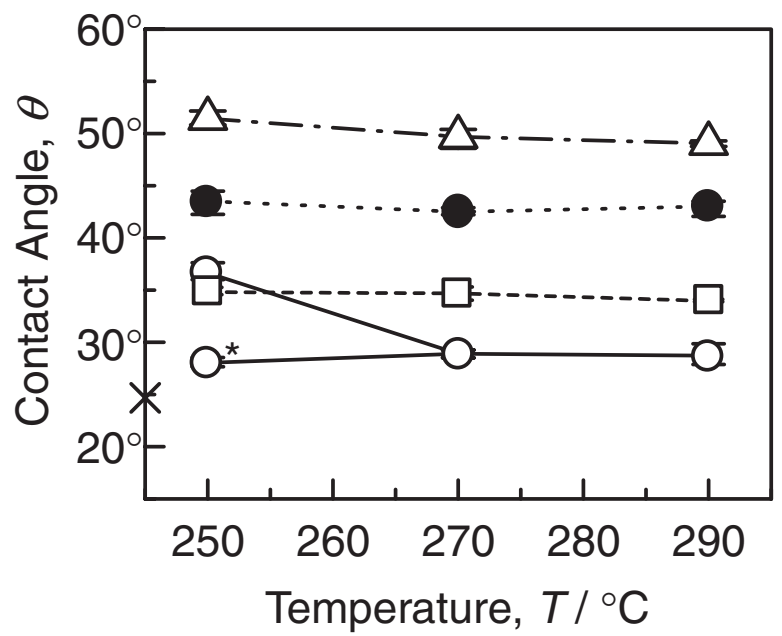

Fig. 8 Contact angle for the wetting between $\mathrm{Sn}-3.5 \mathrm{Ag}$ solder and the metal-coated $\mathrm{Cu}$ substrate; $\bigcirc: \mathrm{Au} / \mathrm{Cu}, \square: \mathrm{Ag} / \mathrm{Cu}, \triangle: \mathrm{Pd} / \mathrm{Cu}, \bigcirc: \mathrm{Cu}, \times$ : $\mathrm{Sn}-37 \mathrm{~Pb}$ wetting $\mathrm{Cu}$ substrate at $230^{\circ} \mathrm{C}$ and $\mathrm{O}^{*}: \mathrm{Au} / \mathrm{Cu}$ substrate $9 \mathrm{~s}$ after the immersion began at $250^{\circ} \mathrm{C}$.

Table 3 Influence of the noble metal coating on the wettability of $\mathrm{Cu}$ substrate by $\mathrm{Sn}-3.5 \mathrm{Ag}$ solder.

\begin{tabular}{lccc}
\hline \multirow{2}{*}{ Wettability } & \multicolumn{3}{c}{ Coating layer on $\mathrm{Cu}$} \\
\cline { 2 - 4 } & $\mathrm{Au}$ & $\mathrm{Ag}$ & $\mathrm{Pd}$ \\
\hline Wetting time & $\circ$ & $\bigcirc$ & $\Delta$ \\
\hline Wetting force & $\odot$ & $\odot$ & $\Delta$ \\
\hline Contact angle & $\odot$ & $\odot$ & $\triangle$ \\
\hline ๑: better, $\bigcirc$ : same, $\triangle$ : worse compared to uncoated $\mathrm{Cu}$.
\end{tabular}

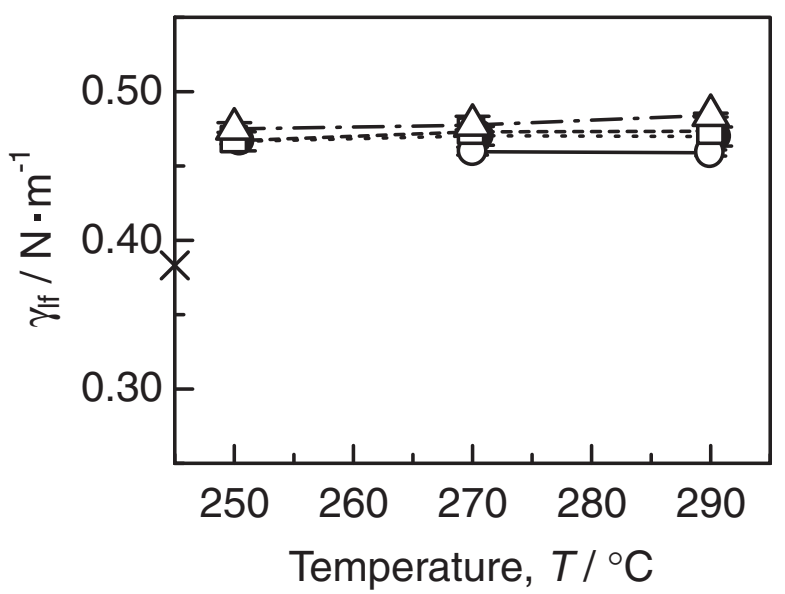

Fig. 9 Interfacial tension $\gamma_{\text {lf }}$ for the wetting between $\mathrm{Sn}-3.5 \mathrm{Ag}$ solder and the metal-coated $\mathrm{Cu}$ substrate; $\mathrm{O}: \mathrm{Au} / \mathrm{Cu}, \square: \mathrm{Ag} / \mathrm{Cu}, \triangle: \mathrm{Pd} / \mathrm{Cu}, \bigcirc: \mathrm{Cu}$ and $\times$ : $\mathrm{Sn}-37 \mathrm{~Pb}$ wetting $\mathrm{Cu}$ substrate at $230^{\circ} \mathrm{C}$.

surface with $\mathrm{Au}, \mathrm{Ag}$ and $\mathrm{Pd}$ is attributed to the variation in $\gamma_{\mathrm{sf}}-\gamma_{\mathrm{sl}}$.

The substrate-flux interfacial tension $\left(\gamma_{\mathrm{sf}}\right)$ is considered to be different from one coated substrate to another because $\gamma_{\mathrm{sf}}$ is influenced by the surface of the noble metal-coated $\mathrm{Cu}$ substrate. On the other hand, $\gamma_{\mathrm{sl}}$ is likely to be affected by the interaction between the solder and intermetallic compound, which is formed at the interface between the solder and substrate.

The same intermetallic compound, $\mathrm{Cu}_{6} \mathrm{Sn}_{5}$, was formed at 


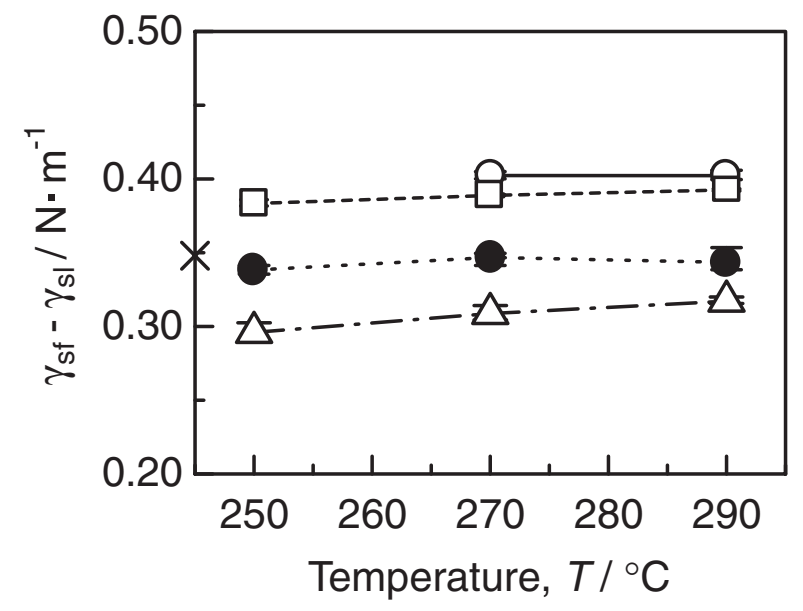

Fig. 10 Interfacial tension $\gamma_{\mathrm{sf}}-\gamma_{\mathrm{sl}}$ for the wetting between $\mathrm{Sn}-3.5 \mathrm{Ag}$ solder and the metal-coated $\mathrm{Cu}$ substrate; $\bigcirc: \mathrm{Au} / \mathrm{Cu}, \square: \mathrm{Ag} / \mathrm{Cu}, \triangle: \mathrm{Pd} / \mathrm{Cu}$, $\mathrm{Cu}$ and $\times: \mathrm{Sn}-37 \mathrm{~Pb}$ wetting $\mathrm{Cu}$ substrate at $230^{\circ} \mathrm{C}$.

the solder/substrate interface, on all the substrates studied. This is in good agreement with the previous studies. ${ }^{8,16)}$ In other words, there was no difference caused by the noble metal coating. This is because the noble metal coating layer is very thin $(70 \mathrm{~nm})$ and easily dissolves into the molten solder, and disappears at the interface. This result shows that there is little difference in $\gamma_{\mathrm{sl}}$ among different substrates because $\gamma_{\mathrm{sl}}$ shows the interaction between the $\mathrm{Sn}-\mathrm{Ag}$ solder and the intermetallic compound, $\mathrm{Cu}_{6} \mathrm{Sn}_{5}$.

From these results, the difference in $\gamma_{\mathrm{sf}}-\gamma_{\mathrm{sl}}$ for different substrates, as shown in Fig. 10, is considered to result from the difference in $\gamma_{\text {sf }}$. The decrease in $\theta$ and hence, the improvement in wettability by coating the $\mathrm{Cu}$ surface with $\mathrm{Au}$ and $\mathrm{Ag}$ is attributed to the increase in $\gamma_{\mathrm{sf}}$ by the $\mathrm{Au}$ and Ag coatings. On the other hand, the increase in $\theta$ and hence, the degradation of wettability by coating the $\mathrm{Cu}$ surface with $\mathrm{Pd}$ is attributed to the decrease in $\gamma_{\mathrm{sf}}$ by the Pd coating.

Consequently, for the improvement of the wettability by the noble metal coating, it is important that the same intermetallic compound as that on the $\mathrm{Cu}$ substrate without a coating is formed, and that the noble metal coating layer remains in the non-wetted area.

The influence of the intermetallic compound on the wettability, especially $\theta$, was evaluated using the pure Au, $\mathrm{Ag}$, and Pd substrates. Figure 11 shows $\theta$ and $\gamma$ for the pure $\mathrm{Au}, \mathrm{Ag}$ and $\mathrm{Pd}$ substrates wetted by the $\mathrm{Sn}-\mathrm{Ag}$ solder in comparison with those for the $\mathrm{Au} / \mathrm{Cu}, \mathrm{Ag} / \mathrm{Cu}, \mathrm{Pd} / \mathrm{Cu}$ and $\mathrm{Cu}$ substrates mentioned above. The test temperature was $270^{\circ} \mathrm{C}$.

The values of $\theta$ for the pure $\mathrm{Au}, \mathrm{Ag}$ and $\mathrm{Pd}$ substrates are larger than those for the $\mathrm{Au}, \mathrm{Ag}$ and $\mathrm{Pd}$-coated $\mathrm{Cu}$ substrates, respectively. From the comparison of $\gamma$ for different substrates, while $\gamma_{\text {lf }}$ shows almost the same values independent of the substrate species, the $\gamma_{\mathrm{sf}}-\gamma_{\mathrm{sl}}$ values for the pure $\mathrm{Au}, \mathrm{Ag}$ and $\mathrm{Pd}$ substrates are smaller than those for the $\mathrm{Au}$, $\mathrm{Ag}$ and $\mathrm{Pd}$-coated $\mathrm{Cu}$ substrates, respectively. It is suggested that the decrease in $\gamma_{\mathrm{sf}}-\gamma_{\mathrm{sl}}$ results from the increase in $\gamma_{\mathrm{sl}}$ because there is less difference in $\gamma_{\mathrm{sf}}$ when the surface of the substrate is consisted of the same kind of metal, such as the $\mathrm{Au}$ and $\mathrm{Au}$-coated $\mathrm{Cu}, \mathrm{Ag}$ and $\mathrm{Ag}$-coated $\mathrm{Cu}, \mathrm{Pd}$ and $\mathrm{Pd}-$ coated $\mathrm{Cu}$ substrates, respectively. The difference in $\gamma_{\mathrm{sl}}$ is
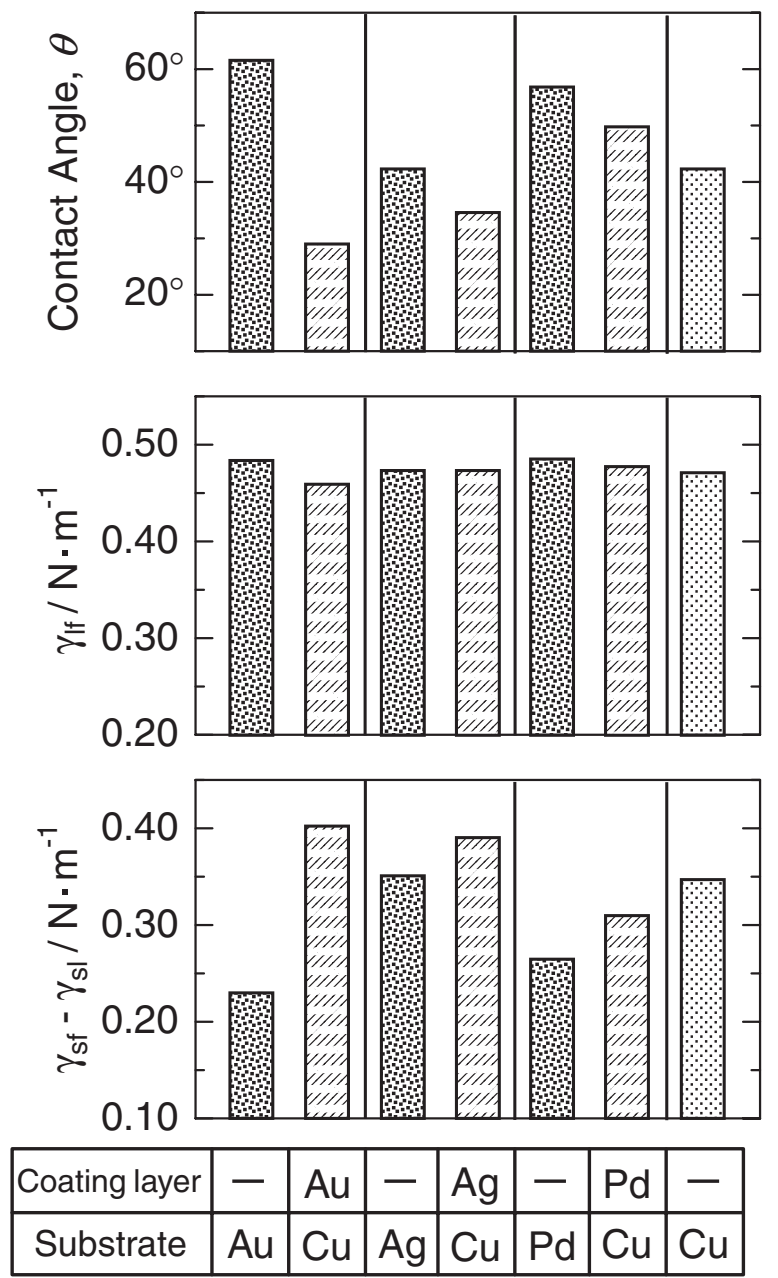

Fig. 11 Contact angle and interfacial tensions for the wetting between Sn$3.5 \mathrm{Ag}$ solder and the metal-coated $\mathrm{Cu}$ substrate, and the pure metal substrate at $270^{\circ} \mathrm{C}$.

considered to result from that in the intermetallic compound which is formed at the interface between the Sn-Ag solder and each substrate. In fact, by X-ray diffractmetry, it was identified that, on the pure $\mathrm{Au}, \mathrm{Ag}$ and Pd substrates wetted by the $\mathrm{Sn}-\mathrm{Ag}$ solder, the intermetallic compound is $\mathrm{AuSn}_{4}$, $\mathrm{Ag}_{3} \mathrm{Sn}$ and $\mathrm{PdSn}_{4}$, respectively, all of which were different from that on the noble metal-coated $\mathrm{Cu}$ substrate. These results also suggests that the wettability of the $\mathrm{Cu}$ substrate decreases if the thickness of the Au and Ag coatings is too thick to disappear at the solder/substrate interface through dissolution into the molten solder.

Based on these results, it is concluded that, in order to improve the wettability of the $\mathrm{Cu}$ substrate with the $\mathrm{Sn}-\mathrm{Ag}$ solder by the noble metal coating, it is important to select the coating metal which has the large $\gamma_{\text {sf }}$ value, and to optimize the coating thickness to suppress an increase in $\gamma_{\mathrm{sl}}$.

\section{Conclusion}

The influence of the noble metal coating on the wettability of a $\mathrm{Cu}$ substrate by $\mathrm{Sn}-3.5 \mathrm{Ag}$ solder was studied using the meniscograph method combined with the contact angle measuring system developed by us. The following conclusions were derived from the present study. 
(1) The wettability of the $\mathrm{Cu}$ substrate with $\mathrm{Sn}-3.5 \mathrm{Ag}$ solder is improved by $\mathrm{Au}$ and $\mathrm{Ag}$ coatings on the $\mathrm{Cu}$ substrate, showing that $\theta$ decreases and $F_{\max }$ increases though there is little influence on the wetting time.

(2) The wettability of the $\mathrm{Cu}$ substrate with $\mathrm{Sn}-3.5 \mathrm{Ag}$ solder is degraded by the $\mathrm{Pd}$ coating on the $\mathrm{Cu}$ substrate, showing that $\theta$ increases and $F_{\max }$ decreases, and the wetting time becomes slightly longer.

(3) It was clarified that, by measuring the contact angle using the meniscograph method, the difference in the wetting force by the $\mathrm{Au}, \mathrm{Ag}$ and $\mathrm{Pd}$ coatings on the $\mathrm{Cu}$ substrate is attributed to the difference in magnitude of $\theta$, not that of $\gamma_{\text {If }}$ for each substrate.

(4) The decrease in $\theta$ by the Au and Ag coatings on the $\mathrm{Cu}$ substrate is attributed to the following: For the Au and $\mathrm{Ag}$ coatings on the $\mathrm{Cu}$ substrate, the coating layer remaining at the non-wetted area up to the tip of the molten solder resulted in an increased $\gamma_{\mathrm{sf}}$.

(5) The increase in $\theta$ by the Pd coating on the $\mathrm{Cu}$ substrate is attributed to the decrease in $\gamma_{\text {sf }}$ by the Pd coating.

(6) In order to improve the wettability of the $\mathrm{Cu}$ substrate with the Sn-Ag solder by the noble metal coating, it is important to select the coating metal which has the large $\gamma_{\mathrm{sf}}$ value, and to optimize the coating thickness to suppress an increase in $\gamma_{\mathrm{sl}}$.

\section{REFERENCES}

1) K. Suganuma: ESPEC Technology Report, No. 13 (ESPEC Corp., Osaka, 2003), 1-8

2) P. T. Vianco and D. R. Frear: JOM, 45 (1993) 14-19.

3) P. T. Vianco, I. Artaki, A. M. Jackson and J. H. Sampala: US DOE Rep., SAND-94-0140-C (1994) 23p.

4) S. K. Kang and A. K. Sarkhel: J. Electron. Mater. 23 (1994) 701-707.

5) H. Steen: Electron. Pack. Prod. 34 (1994) 32-36.

6) P. T. Vianco: Circuit World 25 (1998) 6-24.

7) H. Takao and H. Hasegawa: J. Japan Inst. Metals 63 (1999) 565-568.

8) C. Y. Liu, J. Li, G. J. Vandentop, W. J. Choi and K. N. Tu: J. Electron. Mater. 30 (2001) 521-525.

9) C. M. Liu, C. E. Ho, W. T. Chen and C. R. Kao: J. Electron. Mater. 30 (2001) 1152-1156.

10) Japanese Standards Association: JIS C 0053 (Japanese Standards Association, Tokyo, 1996)

11) H. Takao, T. Tsukada, K. Yamada, M. Yamashita and H. Hasegawa: J. Japan Inst. Electron. Pack. 6 (2003) 488-495.

12) K. Yamada and S. Yamamoto: IEICE Trans. D J79-D-II (1996) 374384.

13) R. J. Klein Wassink: Soldering in Electronics, trans. by T. Takemoto and S. Fujiuchi, (THE NIKKAN KOGYO SHIMBUN, LTD., Tokyo, 1986).

14) K. Yamada, M. Nakano and S. Yamamoto: T. IEE Japan 115-C (1995) 396-402.

15) T. Young: Trans. Roy. Soc. 95 (1805) 65-87.

16) W. Yang, R. W. Messler, Jr. and L. E. Felton: J. Electron. Mater. 23 (1994) 765-772. 